\title{
The Beginning and the Narration of Ivan Slamnig's Novel Bolja polovica hrabrosti
}

\author{
ISTVÁN LADÁNYI*
}

Pannon Egyetem Magyar és Alkalmazott Nyelvtudományi Intézet, H-8200 Veszprém, Wartha Vince u. 1. Institute for Hungarian and Applied Linguistics, University of Pannonia (Veszprém)

Received: 1 June 2020 - Accepted: 7 August 2020

Published online: 15 July 2021

(c) 2021 The Author

\section{ANNOTATION}

The study discusses Ivan Slamnig's novel entitled Bolja polovica hrabrosti with focusing on the narrative features of the beginning of the novel. Using the results of the Croatian literary studies, the paper places the novel in the context of Croatian prose as the first postmodern Croatian novel and an outstanding example of Beat literature in Croatia and Yugoslavia, which Aleksandar Flaker called jeans prose.

The paper compares the narrative features and metapoetic meanings of the beginning of the novel with the narration of the whole novel and its closure. It establishes that the beginning of the novel gives a dominant role to eventuality, coincidence, and meaninglessness instead of causally motivated storytelling. The beginning of the novel does not make sense at the level of the story told in the whole novel, however, it is important at the metalevel of narration and in its possible readings.

The main character of the novel called Flaks lands without a known aim after escaping from somewhere. At the end of the novel, he escapes again from the story prescribed for him. The "story within a story" structure has an important role in the novel. The novel thus has two narrators and two narrated stories. According to Genette's classification, the narrator of the whole novel (Flaks) is an extradiegetic-homodiegetic narrator of his own story. The other narrator (Aunt Matilda) is a character in Flaks's story and fictive author of the embedded story with its own heterodiegetic narrator. Flaks is an implied reader of Matilda's short story. The two narratives are in a metadialogue with each other. Flaks has no organized life and no organized story. Matilda's life is well organized, and her written short story is well organized, too. Matilda tries to make sense to the random happenings of Flaks's life in her own story. With the story she tells, she tries to bring both her own and Flaks's life story to a meaningful end.

* Corresponding author. E-mail: ladanyi.istvan@mftk.uni-pannon.hu 
The beginning of the novel is associated with the characteristics of the Yugoslavian version of Beat literature, the jeans prose: generational confrontation and the denial of conformism to the post-war Yugoslavian establishment. The protagonist's drifting without any plan, which is typical for the genre, is taken by Slamnig as a basis so that he can direct our attention to the activity of the implied author and to the fact that the events portrayed in the novel and also the implied author are constructed. This is reinforced by the "story within a story" structure. The novel shows that the beginning and the ending of the events in the narration is arbitrary, and the meaning of the story depends on the selection of the starting point and the end point.

\section{KEYWORDS}

postmodern novel, jeans prose, Beat literature, story within a story, constructedness, coincidence, implied author, implied reader, homodiegetic narration, heterodiegetic narration

Ivan Slamnig's ${ }^{1}$ Bolja polovica hrabrosti published in $1972^{2}$ is considered later by Croatian literature historians to be the first Croatian postmodern novel (Milanja 2001: 45, NemeC 2003: 256, Jukić 2006, Jukić 2011). Especially its "story within a story" structure, autoreferential and metatextual narrative procedures were the main arguments for its postmodern reading. ${ }^{3}$ The novel is also listed to the genre of jeans prose (in Croatian: proza u trapericama) - with a young intellectual character in the focus who tends to postpone decisions and hesitates to act, and a group of young people like him. The term jeans prose coined by Aleksandar Flaker actually links the novel to the Eastern European Beat literature (FLAKER 1976). Beat culture gained prominence in the former Yugoslavia in the late 1950s and 1960s, giving voice to the young generations, their groups, communities, the crisis of values in the post-war periods, anti-conformism of the groups of young intellectuals, their aimlessness, escape from obligations, etc. As Danijela Lugarić explains, "Flaker's model of jeans prose is based on the antagonism of the novel's protagonists (primarily from Central and Eastern European literature) towards the world of adults, rural prose, and consumerist cosmopolitanism (»the world of hi-tech and material prosperity, the world of the establishment « - FLAKER 1983: 62). [...] Although all heroes are oriented towards the future (»not everything is lost yet « - Šljan), they do not necessarily wear jeans: the jeans motive symbolizes the ironic superiority and oppositional attitude of the hero (individual) gang towards the Other of everyday culture" (LugARIĆ 2008: 97-98).

The way the novel begins is characteristic of the whole novel's meaning making: the beginning of the novel does not make sense at the level of the story told in the whole novel, however, it is important at the metalevel of narration and in its possible readings. A beginning that fails to elu-

1 Ivan Slamnig (1930-2001) was a Croatian poet, literary theorist, and writer of short stories. His late modern poetry is highly regarded by Croatian literary history. Bolja polovica hrabrosti [The better part of valour] is his only novel. It is a highly canonized work of Croatian literature, it has been at the centre of literary historians' interest for decades, and it is one of the high school compulsory readings.

2 The whole novel was not translated to English. For the translated fragment, see SLAmnIg 2004b. The quotes were translated by the author of this paper.

3 The central reference works in the Croatian discourse on postmodernism are WAUGH 1984, McHALE 1987, and Hutcheon 1988. For the Croatian reception of Slamnig's novel, see Grgić 2010: 262-266 and TADIĆ-ŠoKAC 2009: 91-93. 
cidate antecedent events and the easy, irregular, and often frivolous narration, in which Slamnig applies the slang used by the contemporary youth, are characteristic of the prose of the young generation in the 1960 s, i.e. the jeans prose.

This prose favours surprisingly banal beginnings of novels. As one of the antecedents of that prose, very popular in Yugoslavia in the sixties of the last century, ${ }^{4}$ The Catcher in the Rye by J. D. Salinger begins with occasional and incidental sentences, Salinger's Yugoslavian followers also liked to use surprisingly banal, insignificant beginnings with low-style language, slang, and disorganized sentences. Antun Šoljan's novel Kratki izlet [A brief excursion, 1965] starts with the sentence "I'll start right off by saying that my friend Roko is a madman" (ŠolJAN 1999: 3). The beginning of the Bora Ćosićs novel Uloga moje porodice u svetskoj revoluciji [My family's role in the world revolution, 1969] is a description of a hand-made bag for the old newspapers that were used in the toilet in the narrator's family when he was a schoolboy, and that time he wrote a homework on this bag. In the first sentence of the László Végel's novel Egy makró emlékiratai [Memoirs of a pimp, 1968], the narrator-protagonist says: "Today, I finally managed to find the time to check out chequered shirts for a whole afternoon" (VÉGEL 1967). The beginning of Ivan Slamnig's novel is particularly emblematic in this regard.

The striking eventuality of the novel's beginning and its elaborate insignificance, i.e. radical meaninglessness are emphatic; the novel fulfils the requirements of the jeans prose; moreover, it tops the characteristics of the genre. Slamnig starts the plot of his novel by a rather stereotyped event, a class reunion - more exactly, a come together of former classmates at a pub. A couple of insignificant events, which happen accidentally and which are narrated by the first-person protagonist, lead to this scene. The main character, by his nickname Flaks, appears also accidentally in the very middle of the events of the come together, while he is looking for a parking site in the centre of Zagreb; the reader comes to know nothing about the preceding events:

I decided to stop so that I could relax. I was driving on my own and passersby generally do not notice you when you are just sitting in your car but you can see everything around you. Every day and every moment it was like telling myself that I could cope with everything if I didn't keep on running. Right. I'll calm down. There is a vacant parking space in front of the ones for taxi cabs. We're gonna sit still, ain't we? My eyes were wandering all over the dashboard, the funny-looking gear lever, the hand-brake handle, and then I looked down on the clutch, the brake, and the accelerator pedal. As if a man were created for the car; each of our extremities has its function. It's like: What would we do without a car? How would we go to the gas station for petrol?

\footnotetext{
4 The first Serbo-Croatian translation of the Salinger's novel in the former Yugoslavia was published in 1958 (J. D. Salinger: Lovac u žitu. Prev. Nikola Kršić. Sarajevo: Svjetlost, 1958). The second edition of the same translation was published in 1963.

5 The first sentences were translated by the author of this paper.

6 "Odlučio sam da se zaustavim i da se smirmim. Bio sam sâm u autu, a ljudi u pravilu ne primjećuju čovjeka koji sjedi u autu makar da on vidi sve oko sebe. Svakodnevno, svakoga trenutka kao da sam govorio samome sebi da bi se sve moglo sračunati samo kad bih se smirio, kad ne bih besprekidno usplahireno srljao. Okej, sada ćemo se smiriti. Mjesta za parkiranje ima, ispred prostora predvidenoga samo za taksije.

Tako. Sjedimo na miru, zar ne? Promatrao sam komandnu ploču, smiješnu ručku mjenjča, kočnicu, a dolje pedali kuplunga, kočnice, gasa. Kako je čovjek zgdono stvoren za auto! Svi ekstremiteti imaju svoju službu. To je kao ono: što bi čovjek činio bez auta? Čime bi išao po benzin?" (SLAMNIG 2004a: 5).
} 
We do not learn about the reason for the protagonist's uneasiness, where he is coming from, and actually, where he is heading for.

After having stopped the car and speculating for as long as two paragraphs what he is supposed to do just now and what he is supposed to do generally, he will come to the conclusion that all he has got to do is "to wait for the decision to emerge from the depth". Then he is considering that he should "move by car". ${ }^{8}$ During his repose, he is disturbed by a lorry loaded with beer crates, which are pulling down near his car.

It turns out from the strikingly overcomplicated description of the events that the protagonist's car is obstructing the passage of the workers unloading the beer crates; however, "he was unheeded", 9 the workers take cognizance of the fact that they have to unload the crates over the protagonist's car blocking the way. Nonetheless, Flaks is caused by the situation to act; he would not like to bar the way, so he moves his car to another place. This one is much narrower but he receives unwanted help from a meddler, who in return for his unnecessary assistance gets Flaks to invite him for a spritzer. Flaks cannot choose but goes with this nuisance to the Blue Pheasant's, which he did not plan to do at all. At the pub, he happens to recognize his former classmates, who are inclined to think that Flaks must have forgotten the reunion.

Slamnig starts the novel with this unexpected encounter, and thus he makes the beginning of the story accidental. The narrator-protagonist conspicuously does not speak about the antecedent events. He does not say where he came from in the situation that started the novel, and why he needs to calm down. The protagonist of the novel seems to be fleeing into the novel's starting situation from a previously irresolvable conflict that he does not want to talk about. He has to slow down (so he went fast before) and to calm down (so he was tense and nervous before) but the narrator does not talk about the reasons. At the beginning of the novel, the problem of memory and forgetting becomes particularly important. Flaks forgets he has a meeting with his classmates (but accidentally arrives); everyone remembers differently the events of the old school trip; the venue for the meeting, the restaurant has been renovated but Flaks no longer remembers what it was like before. The novel shows that the beginning and the ending of the events in the narration is arbitrary, and the meaning of the story depends on the selection of the starting point and the end point. The beginning of Slamnig's novel is not an absolute beginning, nor is the closure a complete ending.

The protagonist's drifting without any plan, which is typical for the genre, is taken by Slamnig as a basis so that he can direct our attention to the activity of the implied author (Bоотн 1983: 74-75) and to the fact that the events portrayed in the novel and also the implied author are constructed. This is reinforced by the "story within a story" structure.

After the come together, the former classmates leave Flaks alone with Zita, who had previously offered her help to him in preparing his doctoral thesis in language history. She gives Flaks access to the 19th-century correspondence of her family and later, she will bring him to her family estate near the church and cemetery, where there are inscriptions on tombstones which are of Flaks's special interests. Escorting Zita home, he makes acquaintance with her niece Anita, with whom he will have a casual love affair; and he also meets Zita's spinster aunt, Matilda, with whom he

“...da pričekam da odluka isplovi iz dubine” (SLAMnig 2004a: 5).

"Radilo se o nekom pokretu autom" (SLAMNig 2004a: 5).

“...nisu se obazirali na mene" (SLAmNig 2004a: 5). 
will have an intellectual relationship. In fact, the beginning of the novel offers three possible love relationships.

The aunt's identity is the opposite of Flaks's identity. His name is the Croatian pronouncing of the English word flux, referring also to the meaning 'flow'. Thus, Slamnig implies to the traits of Flaks, which can be described by the words fluid, changeable, being in the move. Her well-formed "auntyness" has roots in the soil of traditions; she dresses in a timeless way; her behaviour and status create a tradition around her that has never existed. She is an amateur writer who fills the hiatus of the Croatian literary history by creating very regular texts which could have been written in their earlier epoch according to the rules of the contemporary prose. Thus, she posteriorly makes the past more perfect and more complete through adding to it pieces of art that were not realized then but which seem to be necessary now. The aunt shares the completed sections of one of her short stories in sequels with Flaks, whose experiences as a reader - with the manuscript of the short story - will make part of the novel. The short story begins in accordance with the realist traditions of the 19th century. The aunt's narrator is focusing from the distance, from the sea upon the town which is lying hidden along the seashore, where the story is going to take place and then the narration is gradually coming closer to the heroine of the short story. While approaching the scene, the aunt makes a narrative trap, she offers the reader the opportunity to decide to enter the story or not. The unknown story offered to the reader by the narration is the temptation of the unknown future, unknown opportunities. The traveller who happened to arrive here can still decide to sail away from the unknown story he had not opened yet, or he can choose to set foot on the shore.

In the story taking place in the 1930s and 1940s, at the beginning of their marriage, the young wife creates new types of custom but she makes them look as if these came from her own family tradition. As a young wife, she prepares "traditional" dishes for his husband's first name day and thus she creates her own old tradition. The young wife incorporates her own story into a tradition she invented herself, creating a false continuity instead of a beginning. All of this takes place in the context of World War II, where the armies (Croats, Italians, Germans, and Partisans) that enter the small town also explain their rights to the area with their own traditions and historical narratives that began at different times. The stories about the past are actually about the imagined future.

The novel thus has two narrators and two narrated stories. According to Genette's classification (in Figures III, see GenETte 1983: 228-234, 248-249), Flaks is an extradiegetic-homodiegetic narrator of his own story. Aunt Matilda is a character in that story and a fictive author of the embedded story with its own heterodiegetic narrator. Flaks is an implied reader of Matilda's short story. Flaks has no organized life and no organized story. His stories have only random beginnings, without organized and meaningful continuation and completion. Matilda's life is well organized, and her written short story is well organized, too. Certain elements and problems of the first-level narration will become recognizable in the details of the narrated story on the second level. Matilda tries to make sense to the random happenings of Flaks's life in her own story. With the story she tells (on the second level), she tries to bring both her own and Flaks's life story to a meaningful end (on the first level of the narration).

The story in the past told by the aunt is indirectly a decent, acceptable interpretation of her own present and past. The end of her story, which is left unfinished, is not else than a potential joint destiny offered to the vague, drifting young man. The short story is meant to be, from its beginning, a narrative love trap, which awaits the meaning-making reading of Flaks. The aunt's 
narration has the aim to reconstruct and to correct the past. This does not only mean creating texts with which she can fill posteriorly the hiatus in Croatian literary history but it also means correcting her own imperfect life as a spinster. Her short story written for Flaks is an intellectual game in which she offers a joint future so that they could correct whatever that was not realized in the past. However, Flaks does not like the idea of rewriting the past in such a way. Flaks - as his name implies - will run away; he flees from continuing the narratives of the past in such a way, he does not want to be the protagonist of the aunt's well-written story. As he was driving into the story and parked his car "to relax", at the end of the novel, he will escape from the story.

He will accept the position of an English teacher at a primary school in the countryside. The final sentence of the novel is an unmarked quotation from Shakespeare's Henry IV said by Falstaff (see also Jukić 2011: 95-96) and an ironic comment on his retreat: "The better part of valour is discretion, in the which better part I have saved my life" (Part 1, Act 5, Scene 4). The first part of the sentence, "The better part of valour" is the title of the novel as well. This highlights and activates in the novel Falstaff's self-irony, compromise, cynicism, and Flaks also flees from critical situations rather than getting into a fight. The beginning and the end of the novel thus reinforce each other. Just as the beginning of the novel does not offer a well-constructed introduction to the story, the closing does not promise any meaningful sequel.

\section{REFERENCES}

Воотн 1983 = Воотн Wayne: The Rhetoric of Fiction. Chicago: University of Chicago Press, 1983.

FlakeR 1976 = FlakeR Aleksandar: Proza u trapericama. Zagreb: SNL, 1976.

FLAKER 1983 = FLAKER Aleksandar: Proza u trapericama: prilog izgradnji modela prozne formacije na gradi suvremenih književnosti srednjo- $i$ istočnoevropske regije. Zagreb: Liber, 1983.

Genette 1983 = Genette Gerard: Narrative Discourse. An Essay in Method. Ithaca, New York: Cornell University Press, 1983.

GrGIĆ 2010 = GrGIĆ Kristina: Slamnigov postmoderni bijeg. Dani Hvatskoga kazališta. Građa i rasprave o hrvatskoj književnosti i kazalištu 36 (2010): 262-288.

Hutcheon 1988 = Hutcheon Linda: A Poetics of Postmodernism: History, Theory, Fiction. London-New York: Routledge, 1988.

Jukić 2006 = Jukić Tatjana: Zelene, gorke, namještene. Povijest (i) granice u slamnigovoj Boljoj polovici hrabrosti. In: BenčIć Živa, FališEvac Dunja (ured.): Čovjek, prostor, vrijeme. Književnoantropološke studije iz hrvatske književnosti. Zagreb: Disput, 2006. 367-388.

Jukić 2011 = Jukić Tatjana: Mazohizam i melankolija. Ivan Slamnig: Bolja polovica hrabrosti. In: Jukić Tatjana: Revolucija i melankolija. Granice pamćenja hrvatske književnosti. Zagreb: Naklada Ljevak, 2011. 95-197.

Lugarić 2008 = Lugarić Danijela: Jeans style. Aleksandar Flaker and popular culture. In: KulCsár SzABó Ernő, OraIĆ Tolić Dubravka (eds.): Kultur in Reflexion. Beiträge zur Geschichte der mitteleuropäischen Literaturwissenschaften. Wien: Braumüller, 2008. 93-102.

McHale 1987 = McHale Brian: Postmodernist Fiction. London-New York: Routledge, 1987.

Milanja 2001 = Milanja Cvjetko: Hrvatska književnost i postmoderna na primjeru Slamnigova romana. Književna revija 2001/1-2: 42-48.

Nemec 2003 = Nemec Krešimir: Povijest hrvatskog romana. Od 1945 do 2000. Zagreb: Školska knjiga, 2003. 
Slamnig 2004a = Slamnig Ivan: Bolja polovica hrabrosti. Zagreb: Večernji list, 2004.

Slamnig 2004b = Slamnig Ivan: The Better Part of Valour (fragment). Relations 2004/3-4: 242-250. https:// www.ceeol.com/search/article-detail?id=116287.

ŠolJan 1999 = ŠolJan Antun: A Brief Excursion and Other Stories. Translated from the Croatian and with a foreword by Ellen Elias-Bursać. Evanston, Illinois: Northwestern University Press, 1999.

TADIĆ-ŠoKAC 2009 = TADIĆ-ŠoKAC Sanja: Metatekstualni postupci u romanu Bolja polovica hrabrosti Ivana Slamniga. Fluminensia 2009/2: 91-113.

VÉGEL 1967 = VÉGEL László: Egy makró emlékiratai. Novi Sad: Forum, 1967. [English translation: Memoirs of a pimp (excerpt). Translated by John K. Cox. https://hlo.hu/ new-work/laszlo_vegel_memoirs_of_a_ pimp_excerpt.html.]

Waugh 1984 = Waugh Patricia: Metafiction. The Theory and Practice of Self-Conscious Fiction. LondonNew York: Routledge, 1984.

Open Access. This is an open-access article distributed under the terms of the Creative Commons Attribution 4.0 International License (https://creativecommons.org/licenses/by/4.0), which permits unrestricted use, distribution, and reproduction in any medium, provided the original author and source are credited, a link to the CC License is provided, and changes - if any - are indicated. (SID_1) 